\title{
Organisational and professional challenges amid the evolution of sustainability reporting: a theoretical framework and an agenda for future research
}

\author{
Alessandro Lai and Riccardo Stacchezzini
}

Department of Business Administration, University of Verona, Verona, Italy

\begin{abstract}
Purpose - This paper aims to trace subsequent steps of the sustainability reporting evolution in terms of changes in the organisation fields and professional jurisdictions involved. As such, it highlights the (interrelated) organisational and professional challenges associated with the progressive incorporation of "sustainability" within corporate reporting.
\end{abstract}

Design/methodology/approach - The paper draws on Suddaby and Viale's (2011) theorisation of how professionals reshape organisational fields to highlight how organisational spaces, actors, rules and professional capital evolve alongside the incorporation of sustainability within corporate reporting.

Findings - The paper shows organisational spaces, actors, rules and professional capital mobilised during the recent evolution of sustainability reporting, starting from a period in which there was no space for sustainability, to more recent periods in which sustainability gained increasing momentum beyond initial niches, and culminating in more integrated forms of sustainability reporting.

Research limitations/implications - Although the analysis is limited to empirical evidence collected by prior research and practice on sustainability reporting, the paper offers a view to imagine how the incorporation of sustainability within corporate reporting relies on and affects organisational fields and professional jurisdictions.

Originality/value - The paper offers a lens to interpret corporate and professional challenges associated with the more recent evolutions of sustainability reporting practice and standard setting. It also allows framing the papers accepted in the special issue on "new challenges in sustainability reporting" and concludes by suggesting an agenda for future research.

Keywords Sustainability, Corporate reporting, Integrated reporting, Organisational fields, Professional jurisdiction

Paper type Research paper

(C) Alessandro Lai and Riccardo Stacchezzini. Published by Emerald Publishing Limited. This article is published under the Creative Commons Attribution (CC BY 4.0) licence. Anyone may reproduce, distribute, translate and create derivative works of this article (for both commercial and noncommercial purposes), subject to full attribution to the original publication and authors. The full terms of this licence may be seen at http://creativecommons.org/licences/by/4.0/legalcode

The authors thank all authors and referees who contributed to this special issue. The authors are also very grateful to prof. Charl de Villiers for his helpful guidance during the special issue and for his insightful comments on earlier drafts of the paper. Moreover, the authors thank the reviewers of this paper.

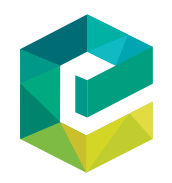

Meditari Accountancy Research Vol. 29 No. 3,2021 pp. $405-429$

pp. $405-429$
Emerald Publishing Limited 2049-372X DOI 10.1108/MEDAR-02-2021-1199 
MEDAR

29,3

\section{Introduction}

Organisations are increasingly incorporating a sustainability mindset within their governance, business model and strategy. In the past, many organisations have treated sustainability as marginal, with only specific departments and experts involved in addressing specific social and environmental issues. A form of "silo thinking" has predominantly driven organisational behaviour, with the exception of a few enlightened organisations that have treated sustainability as their core mission and value (de Villiers et al., 2014, 2020; Dumay and Dai, 2017; Rinaldi et al., 2018).

Times have changed and a number of incentives are now motivating organisations to enact sustainability practices in a more holistic manner: corporate reporting is increasingly required not only to disclose social and environmental performance but also to communicate how sustainability is embedded within corporate vision and governance, informs business strategy and sustains financial performance. Indeed, a more holistic, integrated representation of sustainability is increasingly required from companies by both financial and non-financial stakeholders. Engagement with the United Nations Sustainable Development Goals (SDGs) represents one of the more recent examples of sustainability-related disclosure. Even the sustainability metrics and indexes have increased their diffusion among companies and are monitored with greater attention by investors, as well as other stakeholders. This deep change affects the way corporate reporting transforms over time, with significant effects for how sustainability permeates corporate reports (Bebbington et al., 2014; Unerman et al., 2018).

The "accounting problem" that this paper consequently aims to address refers to the organisational and professional challenges associated with the incorporation of sustainability within corporate reporting. While it is not possible to discuss all the studies in the tumultuous field of corporate (sustainability) reporting, we argue that these studies predominantly deal with the corporate reporting evolution by focusing either on organisational or professional-related challenges. This means that some studies have focused on peculiar aspects of the reporting processes (e.g. the preparation of sustainability reports, assurance mechanisms or disclosure issues), while other papers have devoted attention to the political/professional aspects of the reporting environment, such as focusing on the role of standard setters and similar organisations (e.g. the International Integrated Reporting Council [IIRC]) in modifying the reporting landscape. These studies have predominantly overlooked the interrelations among these kinds of challenges, with very few relevant exceptions (Humphrey et al., 2017).

We thus believe that a deeper exploration of the interrelations between organisational and professional aspects of corporate reporting may help gain a better understanding of the more recent challenges in corporate reporting, which is experiencing increasing incorporation of sustainability matters and their integration with more traditional financial issues. Further, while some studies have developed a longitudinal analysis of sustainability reporting practices and related institutionalisation processes (Contrafatto, 2014; Farooq and de Villiers, 2019), an even longer-term perspective has been overlooked. We believe that a "historical" view of past corporate reporting practices can enhance understandings of contemporary reporting practices (Carnegie and Napier, 1996; Lai et al., 2019a) - particularly for those practitioners and organisations that have "discovered" sustainability more recently (Cho, 2020).

Starting from these premises, this paper explores the (interrelated) organisational and professional challenges associated with the evolution of corporate reporting. In particular, the paper traces subsequent steps of the sustainability reporting evolution in terms of changes in organisation fields and the professional jurisdictions involved, by drawing on Suddaby and Viale's (2011) theorisation of how professionals reshape organisational fields. As such, the paper highlights how organisational spaces, actors, rules and professional capital evolve alongside the incorporation of "sustainability" within corporate reporting. 
Based on empirical evidence collected by prior research and practice on sustainability reporting, the paper shows the organisational spaces, actors, rules and professional capital mobilised during the recent evolution of sustainability reporting, starting from a period in which there was no space for sustainability, to more recent periods in which sustainability gained increasing momentum beyond initial niches, and culminating in more integrated forms of sustainability reporting. As such, the paper offers a view to imagine how the incorporation of sustainability within corporate reporting relies on and influences organisational fields and professional jurisdiction.

The analysis of the sustainability reporting evolution in terms of organisational spaces, actors, rules and professional capital involved helps interpret the organisational and professional challenges associated with the more recent evolutions of sustainability reporting practice and standard setting. It also allows framing of the papers accepted in the special issue on "new challenges in sustainability reporting". Based on the insights collected from prior research and the special issue papers, the paper generates an agenda for future research coherently developed in line with the theoretical frame provided.

\section{The evolution of corporate reporting: key phases}

A debate about the challenges in sustainability reporting requires consideration of how corporate reporting has evolved over the past decades. As the basis of our analysis, we assume a scheme within the IIRC's (2011, pp. 6-7) discussion paper, "Towards Integrated Reporting: Communicating Value in the 21st Century", diffused among practitioners and debated in the integrated reporting literature (Flower, 2015; Thomson, 2015). The scheme synthetically explains the current situation as a result of the subsequent three stages of corporate reporting. This scheme refers to various strands of corporate reports (financial statements, management commentaries, governance and remunerations reports and sustainability reports) and argues that these strands must be better integrated (Flower, 2015, p. 3) to achieve a new reporting framework. For our purposes, the scheme is relevant because it simplifies subsequent phases in the corporate reporting evolution.

\subsection{First phase: 1960 s to 1970 - neglecting sustainability}

From the early 1960s to the end of the 1970s, there was little interest in themes related to sustainability. Corporate reporting mattered for providing financial information, as its boundaries were mainly constructed around a unique central body of knowledge. All around the world, the cultural debate about reporting dealt mainly with the improvement of (financial) accounting standards to attain more transparent reports, making them comparable among industries and different countries.

\subsection{Second phase: 1980 s to 1990 s - experimenting with sustainability niches}

The situation changed rapidly during the final 20 years of the previous century. Accounting was thought of and practised differently, and additional, non-financial knowledge concurred in feeding corporate reporting. There was a need for new matters to be reported alongside those presented in ordinary financial reporting [International Integrated Reporting Council (IIRC), 2011]: more information on business, new governance and compensation matters, environmental questions and social reporting. This shift caused a significant loosening of the identity between "corporate reporting" and "financial reporting"; previously, this identity had been taken for granted and reporting viewed as a homogenous and unique field (Emenyonu and Grey, 1992). 
MEDAR

29,3

408

\subsection{Third phase: 2000s to 2010s - enhancing sustainability}

As a further step, the International Integrated Reporting Council (IIRC) (2011) highlighted that the two first decades of the new century were characterised by a continuous increase in forms of accounting and reporting different from the traditional financial one. At the same time, the IIRC depicted a slow and progressive "substitution" of some types of reporting (mainly, environmental reporting) existing in the previous period and its transformation into "sustainability reporting". This was not a reduction or collapse, but an increase, for two main reasons: inside "sustainability", there are many other themes not related just to the environmental matters, but also to social ones, for instance; and sustainability is not just a "silo" with many themes, but a new perspective that is assuming increased relevance and through which we can "read" all management actions in a new way.

\subsection{Fourth phase: 2020 and onward - integrating sustainability}

In the fourth period, the International Integrated Reporting Council (IIRC) (2011) emphasised the rising of integrated reporting alongside any other type of reporting depicted in the previous periods, including sustainability reporting. Even if this vision (giving relevance to integrated reports) was biased by the nature of the author (the IIRC) and by the circumstances in which it was conceived about 10 years ago, it can currently be re-interpreted as the need and the expectation for a further increase in alternative forms of reporting (in respect to the previous financial one), which is able to offer new challenges (Dumay et al., 2017). This transformation is occurring in connection with the incoming presence of policy makers, regulators and standard setters, who are now pushing for significant changes in reporting and sometimes are - somewhat unexpectedly - drivers of change in definitively enlarging the spectrum of matters to be reported (Rowbottom and Locke, 2016). At the same time, the need perceived by stakeholders seems to encourage more concise reporting, with significant forms of interconnections among its different parts, to allow the reader to understand the way organisations are producing value for all stakeholders.

\section{Corporate (sustainability) reporting and interactions among changes in organisational fields and professional jurisdiction: a theoretical frame}

The evolution in corporate reporting is hereafter interpreted by means of the theoretical lens of a framework that is able to highlight the effects of professional and organisation field-level dynamics, considering the critical yet often invisible role that professionals play in institutional work - that is, in the creation, maintenance and transformation of institutions (Suddaby and Viale, 2011, p. 423). According to this approach, four distinct and sequential mechanisms allow professionals and professionalisation projects to shape organisational fields (Beckert, 2010). The first mechanism is explained as the definition of a new uncontested space (and its related boundaries): professionals advance their project in occupying (or colonising) new intellectual and economic space, which is the space previously occupied by other professions or professionals. Thus, it is a question of jurisdiction (Abbott, 1988) that is modified to allow people to occupy different spaces and define new boundaries that are usually broader than or different from the traditional ones. This is already occurring in accounting professions, which undertook a project of encroachment into the jurisdiction of the related professions (Greenwood et al., 2002; Suddaby and Greenwood, 2005).

The second dynamic refers to how professionals populate the new identified spaces with new categories of legitimate social actors who serve their interests. They often engage in the institutional work necessary to generate new forms of organisation. Multidisciplinary partnerships, as new forms of accounting in professional organisations, are meaningful 
(Suddaby and Greenwood, 2005): non-accountants are brought inside the old accounting organisations to allow and favour the enlargement of old boundaries to establish new ones.

The third dynamics appears as a direct consequence of the previous two when, as we see above, professionals' advance in their jurisdiction is managed by subordinating existing occupations or establishing new areas of practice or new expert occupations (Humphrey et al., 2017, p. 35). In doing so, relevant shifts in the boundaries and rule systems of organisational fields are needed. A key mechanism encourages professionals to use their expertise by promulgating rule systems designated in the broader social system that only professionals reporting understand; this mechanism enables them to change field logics and boundaries, while simultaneously undertaking their professional projects. Many studies show that accountants are fostering rule systems that have a deep influence on market institutions, while also benefitting accounting professions by consolidating their power and legitimacy as the exclusive interpreters of the new rules (Flood, 2011; Venter and de Villiers, 2013).

Finally, a fourth relevant dynamic is related to "social skill" (Fligstein, 2001), whereby professionals must manipulate a social order within an organisational field. This skill is based on their unique access to a large range of different forms of capital, as well as their facility in moving between different forms of capitals (Suddaby and Viale, 2011, p. 434). Thus, this fourth dynamic refers to how professionals manage the reproduction of professional capital through different strategies: rhetoric and categorisation. Rhetoric is used to influence the direction of change and to legitimise or delegitimise the acceptance of a program of change. Categorisation refers to the process by which professionals connect the view of the client's problem to the "dictionary of professional legitimate problems" (Abbott, 1988, p. 41). By means of these two strategies, actors whose behaviour is inappropriate to their role may suffer penalties (Zuckermann, 1999), while social hierarchies within the new fields are created and enforced by membership strategies (determining inclusion or exclusion from the categories), and quality categories and standards are adopted to grant or deny legitimacy to actors or actions within a field.

Suddaby and Viale's (2011) framework is useful to provide a meaningful interpretation of what has occurred in the field of corporate reporting, particularly when the need for new matters to be reported - together with those typical of traditional financial reporting - progressively encouraged organisations to provide new and qualified information on their business models; corporate governance systems and mechanisms, including top management compensation; and environmental and social issues [International Integrated Reporting Council (IIRC), 2011]. Similar to a recent analysis on integrated reporting (Humphrey et al., 2017), we provide an interpretation of these phenomena by examining the connections between professional jurisdictions and changes in organisational fields. In particular, we analyse the interaction between the new needs for disclosure (particularly those typical of sustainability) and practices of reporting by conceiving how these new interactions breed new fields of investigation, corresponding to new organisational fields.

\section{Organisational changes and professional jurisdiction in the sustainability reporting evolution}

The present section details our interpretation of the empirical evidence collected by prior research and practice on sustainability reporting according to the theoretical framework depicted in the previous section. This interpretation is summarised in Figure 1.

\subsection{First period: 1960 s to 1970 s - neglecting sustainability}

During the lengthy period of post-World War II recovery, where a galloping economy would not have been halted by any constraints, new accounting standards were establishing 


\section{MEDAR \\ 29,3}

410
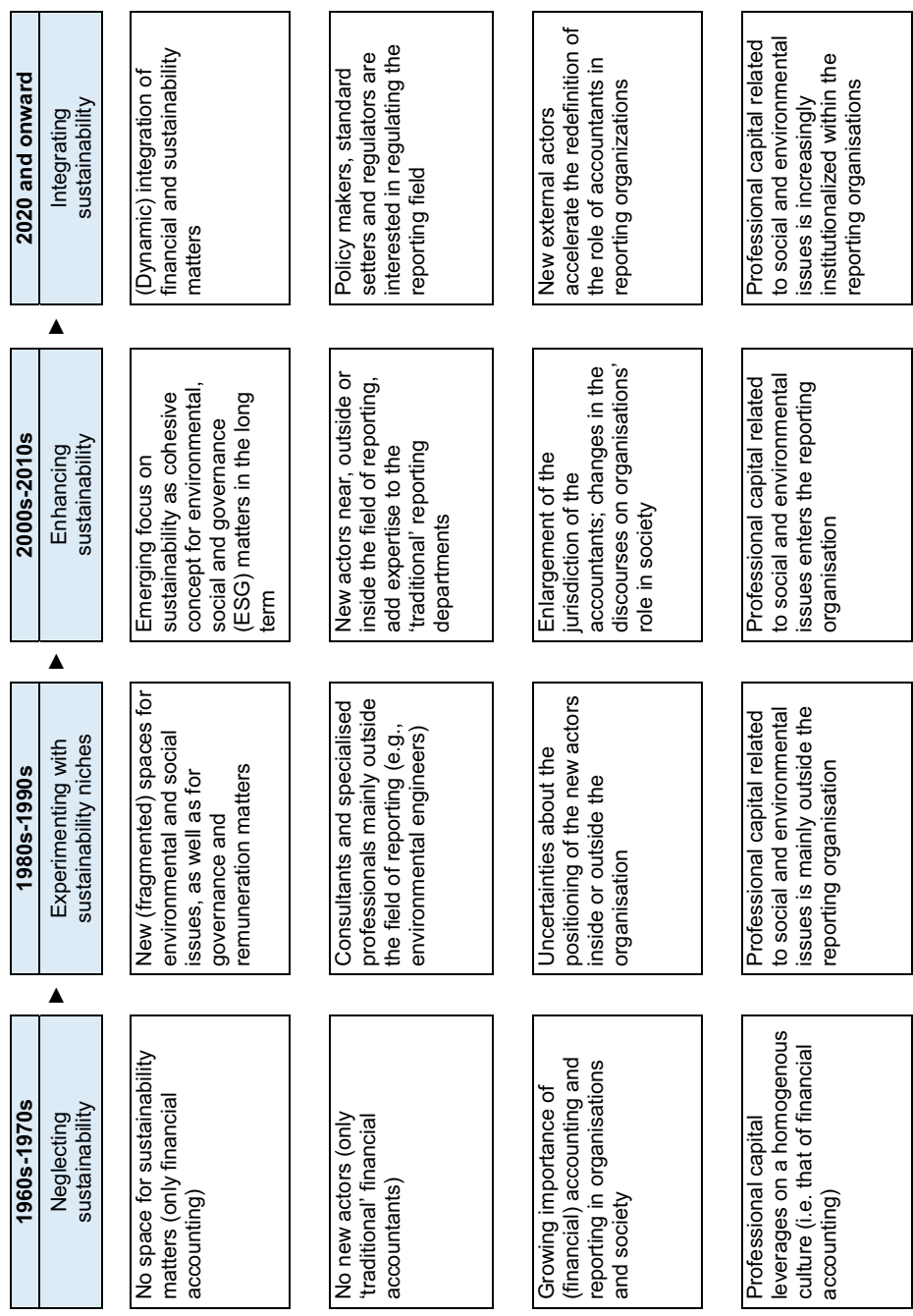

Figure 1.

Organisational and professional

challenges amid the evolution of corporate reporting

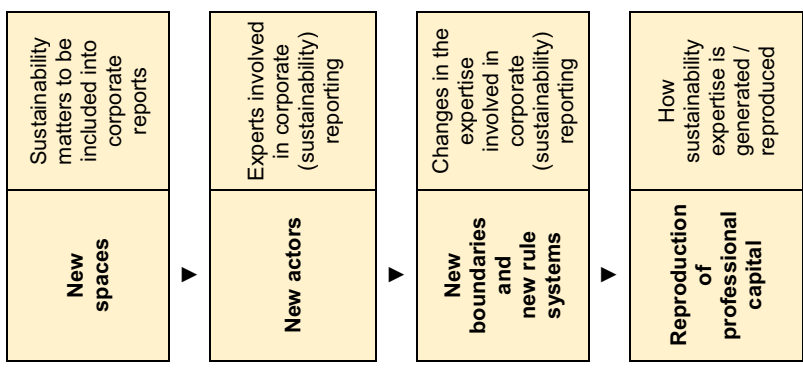


the basis for increased circulation of capital among countries, especially in wide areas converging to a union (as with the European Union), and for a possible reduction of earnings management procedures, which usually undermined the relevance of financial reporting. All ran alongside the growing economy, without any consideration for the wider needs of the planet.

The knowledge of the people dealing with corporate reporting, in the professional world and in research settings, relied entirely on technical financial accounting tools. A homogenous accounting culture (Emenyonu and Gray, 1992) improved the relevance of reporting financial accounting as the main form of corporate reporting. Moreover, parliaments and governments devoted wide attention to financial reporting, strengthening a tradition derived from laws established in the nineteenth century (Deegan and Unerman, 2011) and moving towards more defined and itemised models to be used in mandatory corporate reporting. This homogeneous culture emphasised the role of accountants in civil society (Burchell et al., 1980; Walker, 2016) and diffused the presence of accounting as a topic to be studied in universities. Finally, accounting profession boundaries have been settled, and are now even protected by law.

Inside these borders, accountants - both practitioners and scholars - held their domain, shared a common language, sought generally accepted accounting principles, and pushed their proposals to be implemented as accounting standards or enforced by law. The strength of this homogenous culture allowed corporate reporting to experience huge development, as it never had in previous decades. In corporate reporting settings, accounting meant financial accounting.

\subsection{Second phase: 1980 s to 1990 s - experimenting with sustainability niches}

In the period of the 1980s to 1990s, traditional financial reporting first required enlargement of its previous spaces, owing to new matters to be reported alongside those presented in ordinary financial reporting [International Integrated Reporting Council (IIRC), 2011]: information on business, new governance and remuneration matters, and environmental and social issues. These new themes were mainly just "accepted" by the professionals responsible for corporate reporting, who were mostly unwilling to be involved in environmental or social themes (Gray et al., 1993; O’Dwyer, 2002; Wilmshurst and Frost, 2001).

These themes were perceived not yet as a challenge, but as a necessity to be tolerated. They were often considered outside the professional jurisdiction of the people involved, as they were slow to engage with sustainability issues (Mathews, 1997). Their response to the need for sustainability accounting and reporting mostly reflected unwillingness to become involved in this new domain (Kwakye et al., 2018). Further, the more "traditional" accounting literature was convinced that sustainability remained outside the domain of accounting; as a result, more recently, accounting has become considered a profession unable to integrate economics and sustainable issues (Burritt and Tingey-Holyoak, 2011, p. 108).

To some extent, contrasting behaviours emerged in these periods: simple acceptance of the new sustainability issues; tolerance of the new matters reported; indifference regarding the issues; curiosity towards the issues; willingness to manage the new needs with own resources and staff, as they were considered not too 'technical'; and the need to address the new emerging forms of reporting by requiring the assistance of specialised external professionals. As stated by Bebbington et al. (1994):

Accountants have low levels of involvement in their company's environmental activities and, from responses to personal opinion questions, appear to experience a conflict between their 
MEDAR 29,3 awareness of environmental issues and an inability to translate this into action within their corporate life.

However, after the very first period in which new themes slightly affected reporting, without receiving much importance - the chief financial officer's culture was different (Whelan and Douglas, 2021) - a more conscious perception of these new issues arose, and the main question asked was about the role of accountants and accounting departments within companies and organisations in providing the relevant information about these new themes (Burritt and Tingey-Holyoak, 2011).

Traditional accounting and reporting departments and top management had to decide how to populate the new identified spaces with new categories of actors who served their interests. In this period, the main option was to rely on consultants and specialised professionals outside the fields of reporting (such as environmental engineers), which can be hired or act as external consultants. This was not just a 'technical' decision, as the new social spaces called for relative autonomy by people dealing with the new needs. Thus, there were two main alternative strategies implemented by organisations:

(1) accounting departments took information from consultants and professionals belonging to other areas of the organisation, as the managerial decision was to allow those spaces be occupied by specialists appointed by top management.

(2) accounting departments and their professionals leveraged external knowledge to cover new expertise related to the new streams of reporting.

Both choices allowed accounting departments and their professionals to concentrate on traditional matters. There is considerable literature dealing with the lack of engagement of the accounting profession with environmental, social and sustainability themes (Gray and Collison, 2002; Lamberton, 2005; MacKenzie, 2009). However, these departments and professionals were usually responsible for the final result of the reporting package, so they usually could "have a say" about the non-financial content, as the final report emerged by summing up different parts (Lusher, 2012). The boundaries of accounting and reporting departments did not change significantly, nor did the professional jurisdiction of their actors, as they were somewhat separate from the deep changes occurring, yet were mainly responsible for the final results and had power over the outcome of the reporting process. External consultants acted aside the organisation, with the task of providing the information to be reported in the final document. Thus, the professional capital related to social and environmental issues was mainly outside the reporting organisations.

\subsection{Third phase: 2000 s to 2010 s - enhancing sustainability}

The relevance of environmental and social themes and the change towards an emphasis on sustainability substantially increased during the two first decades of the new century. This provided and still provides a significant opportunity for accountants and reporting managers (Farooq and de Villiers, 2019) to spearhead environmental, social and sustainability management via their active role in accounting and reporting (Kwakye $e$ t al., 2018; Lai et al., 2019b).

The topics highlighted in the previous phase increased momentum under a new lens they started to be conceived with the lens of sustainability, in line with the idea that sustainable development "meets the needs of the present without compromising the ability of future generations to meet their own needs" (United Nations, 1987). These decades saw a continued increase in forms of accounting and reporting different from the traditional financial one [International Integrated Reporting Council (IIRC), 2011] a slow and 
progressive "substitution" of some types of reporting (mainly, environmental reporting) existing in the previous period and its transformation into "sustainability reporting".

A huge increase in the relevance of environmental, social and governance disclosure occurred - increasingly referred to as sustainability. This was demonstrated by new broad streams of literature that provided significant evidence of the relevance of many types of non-traditional accounting and reporting, all over the world (Argento et al., 2019; Del Baldo, 2017; du Toit et al., 2017; Farneti et al., 2019; Guthrie et al., 2017; Ismaeel and Zakaria, 2020; Kassim et al., 2019; McNally et al., 2017; Peña and Jorge, 2019; Suárez-Rico et al., 2019), with some differences between developed and developing countries (Kwakye et al., 2018).

Sustainability, as an evolving concept (Greenwood et al., 2015), was viewed initially as a mixture of eco-social constraints that captured a new way of thinking and united two related changes:

(1) the span of environmental and social matters within sustainability was enlarged to cover more domains with different aims; and

(2) an increasing attitude towards measuring financial results in the long term (Burritt and Schaltegger, 2010, pp. 833-834) in the financial market, rather than focusing only on short-term goals.

The relevance of the long term has been growing alongside a broadened relevance of stakeholders other than shareholders (Burritt and Schaltegger, 2010, pp. 836-837), thereby combining long term with new theoretical views. These transformations rely on the idea of sustainability not as an outcome, but as a process embedded in organisational life (Bansal and Hoffman, 2013). Thus, the attention is also devoted to the business model (Melloni et al., 2016; Sukhari and de Villiers, 2019), which expresses the underlying conceptions, ideas and thoughts shared by board and management, and declares how an organisation produces value for every stakeholder in the long term.

While new sustainability fields were occupied to satisfy new subjects and new domains - as began in the previous period - bringing much expertise inside and outside traditional offices, the problem of considering and facing a relevant sustainability effort arose in the traditional domains of accounting and reporting, bringing an increasing need to change how to tell the organisation. Accountants started to play a significant role in explaining socio-environmental performance, organising environmental auditing, providing accountability, evaluating environmental risks (O'Dwyer and Unerman, 2020) and providing feedback for sustainability policies and performance (Kwakye et al., 2018; Özsözgün Çalişkan, 2014; Wilmshurst and Frost, 2001).

Thus, the introduction of new actors close to sustainability matters - near, outside or inside the field of reporting - not only represented a dynamic resulting from the direction taken in previous decades, when these new spaces began to be populated, but also a question about how the new themes should be intertwined with the old ones. There was not just a need to establish new boundaries around new actors, to protect and isolate their contribution as experts on the new emerging themes, or to place them into a ghetto full of advisors dealing with not strategic matters, but also to redefine the boundaries of the reporting fields, thereby promoting closer interaction among people aimed at providing a more integrated disclosure by drawing on preparers' different modes of cognition (Stacchezzini and Lai, 2020). This was undertaken while social and environmental (sustainability) accountability was progressively embedded into new and old fields (Clune and O'Dwyer, 2020).

A new challenge of this third phase affected the role of accounting departments and their professionals, if they decided or were allowed (by top management) to enlarge their staff to

\section{Sustainability} reporting 
MEDAR 29,3

cover new matters related to the environmental and social (as well as governance) streams of reporting, as is increasingly occurring nowadays (Farooq and de Villiers, 2019). Accountants' knowledge, skills and experience offered them opportunities to play a leading role in the development of environmental and social accounting (Lewis, 2000). In this case, traditional departments were renovated by new expertise, where accountants managed the advance in jurisdiction they needed inside their workplace, controlling their new colleagues and establishing new areas of practice, promoting a new exchange of knowledge between the old experts of financial reporting and the new professionals. The reproduction of intellectual capital entered into accounting departments as the input of new people devoted to the new subjects to be reported. These new subjects needed to be moulded together with traditional reporting, sometime using its categories and rhetoric, as it had developed over a many-decade-long tradition. The female presence in these professional settings has increased in relevance, although women continue to be under-represented at senior levels in all professional fields (Siboni et al., 2016).

Over these past decades, this dynamic has been intertwined with the promulgation of new rule systems, as the idea of implementing sustainability requires deep changes inside organisations (Bansal and Hoffman, 2013). Organisations must be sustainable while pursuing their own goals, thereby determining the need to redefine their purposes, not just the boundaries of reporting departments. It is not only an 'addition' of new themes to those traditionally reported; rather, the needs of the accounting departments and professionals characterising the previous situation require a rethinking, as well as more stable and structured frameworks. This is occurring alongside a rethinking of sustainability themes within a more comprehensive organisational life, where both strategic and operational issues must be conceived in a different way.

Solutions may be varied and not homogeneous in diverse settings, yet involve the creation of staff able to manage sustainability problems in different areas of the organisations, as well as departments specialised in managing specific critical issues. This is why new rules are emerging, and this is determining a reorganisation of the knowledge involved in reporting, as people charged with reporting must be able to manage sustainability themes. New professional capital is required and their reproduction is becoming necessary for the purpose of reporting.

\subsection{Fourth phase: 2020 and onwards - integrating sustainability}

Ten years ago, the International Integrated Reporting Council (IIRC) (2011) imagined for the 2020 s a growing relevance of integrated reporting - not to replace sustainability reporting, but to rest at the centre of the reporting system. The need for disclosure about diverse sustainability themes, as well as many other more traditional financial aspects, caused managers, professional as well as scholars to reflect on the huge enlargement of corporate reporting, which had the undesirable effect of making organisations produce heavy and bulky documents, suffering the risk of not being read by stakeholders (du Toit, 2017; Lai et al., 2017 and 2018), as seeking relevant information inside such reports is often timeconsuming. Despite the great debate on the pros and cons of integrated reporting as a way to provide evidence of sustainability themes (de Villiers and Maroun, 2017; de Villiers and Sharma, 2020) or to explain to financial capital providers how an organisation creates value over time, there can be no doubt about its capability to give new perspectives to corporate reporting. It is widely recognized its active role in proposing an innovative form of reporting and providing the opportunity to generate greater legitimation of a broad vision of a company and/or organisation, in which sustainability attains the role it has in current emerging culture of these times (Bebbington et al., 2014). The relationship between 
sustainability and integrated reporting is growing in both practice and research settings (de Villiers and Maroun, 2017).

Currently, around 10 years after the IIRC's (2011) forecast, we have a clearer idea of the possible evolution of corporate reporting in the decade of the 2020s. There now seems an increasing need for and expectation of a further increase in alternative forms of reporting (beyond the previous financial one), while many stakeholders encourage concise reporting, interconnections among different parts of the subject dealt with in the reports, and a debate about what materiality is. In this new scenario for sustainability reporting, we can identify reporting at least three initiatives that could mould new and challenging paths, with effects on organisational spaces, the actors involved, professional jurisdictions and the intellectual capital involved. The first initiative relates to the IIRC and SASB'S (2020) announcement about their intent to merge, in a major step towards simplifying the corporate reporting system, giving birth to a unified organisation - the Value Reporting Foundation - which has declared it will provide investors and corporations with a comprehensive corporate framework across the full range of enterprise value drivers and standards to drive global sustainability performance. Considering that many organisations are already using both the IIRC Framework and SASB Standards to communicate with investors on how sustainability issues are connected to long-term enterprise value, with these endeavours ultimately benefitting other key stakeholders, the announcement claims that integrated reporting and the SASB standards will link the concepts between them even further (IIRC and SASB, 2020).

The second initiative is the International Financial Reporting Standards (IFRS) Foundation's (2020) consultation paper about sustainability reporting. The declared reason for the paper arose from an informal engagement with a cross-section of stakeholders involved in sustainability reporting, where it became clear that sustainability reporting is continuing to increase in importance for those stakeholders, notwithstanding differences in scope and motivation. However, all stakeholders emphasised the urgent need to improve consistency and comparability in sustainability reporting. According to the IFRS Foundation (2020, p. 4), a set of comparable and consistent standards will allow businesses to build public trust through greater transparency in their sustainability initiatives, which will be helpful to investors and an even broader audience, in a context in which society is demanding initiatives to combat climate change. Thus, the IFRS Foundation is now proposing to become a key player in harmonising sustainability reporting worldwide.

The third initiative is an initiative of the European Commission (European Financial Reporting Advisory Group [EFRAG], 2020), which issued a request for technical advice mandating that the EFRAG undertake preparatory work for the elaboration of possible European non-financial reporting standards in a revised Non-Financial Reporting Directive. The ultimate objective is to allow for the swift development, adoption and implementation of European standards, to be implemented together with the wider revision of the NonFinancial Reporting Directive. Much attention has been deserved to this initiative in the European Union and determined the need to rethink how to consider different interests into non-financial information (NFI) and its materiality (La Torre et al., 2018).

Paradoxically, these three relevant initiatives - all of which indicate an institutionalisation (Dacin et al., 2002; Lawrence and Suddaby, 2006) of sustainability reporting (Farooq and de Villiers, 2019) - offer different directions that can be taken, and demonstrate the debate among actors in the field - that is, the standard setters already engaged in sustainability processes and the newcomers that aim to acquire expertise and legitimation in the field of sustainability reporting (Cho, 2020). These initiatives are determining a 'positive' excitement among actors who usually deal with this issue - at 
MEDAR 29,3

corporate level or in any institution involved in the field of sustainability reporting - such as professionals, managers, executive members of company boards, and researchers in a large spectrum of fields, including accounting and reporting, but not limited to it. Politicians and governors are extraordinary employed in these movements.

The effect of this excitement is the constitution of new spaces inside organisations, where new, hybrid departments must be conceived as rapidly as possible, in alignment with these innovative forms of reporting and the more traditional accounting departments that need to be populated by new experts. To make this process effective, all organisations, including professional bodies and accounting firms, must quickly redefine their professional boundaries and promote a new form of induction to reproduce the intellectual capital needed to be involved.

\section{Framing the papers included in the special issue on new challenges in sustainability reporting}

The sustainability reporting evolution and the related changes in the organisational fields depicted above are reflected in the research papers accepted in this Special Issue of Meditari Accountancy Research on "new challenges in sustainability reporting". They testify how the need to occupy new spaces matters for sustainability reporting, the new social actors to be involved in these processes, the possible debates among professionals about their own jurisdictions in the new fields, and the social skills to be manipulated and managed in the new organisational fields. All these new patterns and issues, which can be found in diverse settings and are very different from one another, demonstrate how these changes are affecting a wide spectrum of situations, not limited by geographical, industrial or social constraints, nor by the different ownership or governance of the organisations involved.

In the study by Patrice De Micco, Loredana Rinaldi, Gianluca Vitale, Sebastiano Cupertino and Maria Pia Maraghini (De Micco et al., 2021), the overall problem of the challenges of sustainability reporting is directly faced, starting from generally accepted accounting knowledge that recognises that corporate performance must be assessed not only on the basis of financial results but also by considering the effects on the social and environmental context. However, the paper reminds us that pursuing the purpose of effective sustainability reporting is not an easy task, as it involves considerable challenges (in terms of understanding, managing and communicating NFI) and related mechanisms (dissemination of sustainability principles, employee involvement, routinisation and institutionalisation of sustainability reporting practices and management commitment) that must be implemented. Two research questions are considered in the paper:

(1) What are the main challenges that firms face over time when dealing with sustainability reporting?

(2) Which mechanisms can be adopted to cope with these challenges?

The authors answer these questions by adopting a holistic approach considering multiple dimensions of sustainability and developing a five-year longitudinal case study of an Italian multi-utility large company.

The quality of non-financial reports (NFRs) is the focus of the paper by Jonida Carungu, Roberto Di Pietra and Matteo Molinari (Carungu et al., 2021), in a scenario where NFR became mandatory under the European Directive no. 2914/95/EU implemented in Italy. The scholars show that this quality does not increase when moving from a voluntary to mandatory basis, especially for companies (about 25\%) that publish supplementary sustainability reports and/or plans. The paper demonstrates that preparers may perceive 
mandatory non-financial reporting as a comprehensive best practice to adequately report their social, economic and environmental performance. The authors find that, in some companies, other sustainability documents (sustainability plans/reports, presentations, etc.) reporting from the 2017 financial year had disclosed specific non-financial aspects more thoroughly, which were the same aspects reported poorly (or absent) in the mandatory NFRs. Some investigated companies (that were previously involved in the process of NFR on a voluntary basis) considered NFR a legal requirement and adopted additional reporting documents to better disclose non-financial matters.

The study by Larissa von Alberti-Alhtaybat, Zaidoon Alhatabat and Khaldoon Al-Htaybat (von Alberti-Alhtaybat et al., 2021) focuses on developing the sustainability habitus by examining, in an Arab Middle East context, the Aramex organisation, which has been pioneering sustainability practices and reporting. Drawing on Bourdieu's habitus and field, the paper explores the evolution of sustainability reporting from 2006 to the integrated report prepared in 2018, underlying the role of Aramex as a contributor to developing a sustainability habitus in the region. The paper offers a significant contribution to the literature on sustainability regarding the Arab world (Ismaeel and Zakaria, 2019) as an under-researched area (O'Dwyer and Unerman, 2016).

The paper by Claire Horner and Neil Davidson (Horner and Davidson, 2021) explores the feasibility of implementing the natural inventory model (NIM) developed by Jones (1996, 2003) in biodiverse corridor plantations, from a non-government organisation (NGO) perspective. The majority of areas identified by Greening Australia Tasmania (GAT) as being essential for these wildlife corridors are on privately owned land, used for agricultural purposes; thus, the paper explores whether stewardship of the land sacrificed by landowners may be demonstrated via the quantification and communication of improvement in biodiversity by using the NIM.

The study by Cristina Florio and Alice Francesca Sproviero (Florio and Sproviero, 2021) explores how a company can repair legitimacy after an environmental disaster. The paper shows the situation of a well-known motorcar company after it deviated from correct and sustainable behaviour, as managers and employees acted in their self-interest, rather than in stakeholders' interests. Environmental issues caused a stock crash of about $22 \%$ in the domestic stock exchange, while US\$30bn was required to address the issues of the company towards customers, dealers and environmental regulators worldwide. Class actions, recalls and maxi-sanctions also contributed to undermining economic stability. In this severe situation, recovering credibility required a huge effort. Drawing on the discursive nature of legitimacy, the paper conducts a critical discourse analysis and highlights the different tools used, inside discourses, to repair pragmatic legitimacy, moral legitimacy and cognitive legitimacy, thus contributing to the growing literature on how organisations face the legitimacy challenges of sustainability scandals.

Dissanayake's (2021) paper explores the extent of the Global Reporting Initiative (GRI) sustainability key performance indicator (KPI) usage in sustainability reporting by businesses located and operating in Sri Lanka, as a developing country, as has been undertaken by few other studies. The paper draws from a contingency theory approach (Chenhall, 2007) to highlight the factors promoting or inhibiting the use of the GRI standards in defining sustainability KPIs. The results show that the GRI framework is increasingly used for sustainability reporting in Sri Lanka owing to its flexibility, consistency, legitimacy and focus on continuous improvement. However, the paper also highlights - based on the opinions of interviewed company managers - the extensive number of KPIs in the GRI frameworks, which requires challenging selections to be adapted for companies operating in a developing country context. According to the author, engaging with sustainability KPIs 
MEDAR 29,3 and reporting extends beyond a conventional mechanism to gain strategic legitimacy (Lai et al., 2016) to importantly signal a certain standard of operations, management of risks and common language to strengthen existing and build new partnerships with foreign companies in global supply chains. However, this could point to a tendency for some companies to adopt an instrumental approach (Stacchezzini et al., 2016) towards the integrative management of corporate sustainability.

The purpose of the paper by Ana Fialho, Ana Morais and Rosalina Pisco Costa (Fialho et al., 2021) is to detect whether the introduction of water security as a category in the Carbon Disclosure Project Climate A-List increases the use of impression management (IM) strategies, by investigating how companies reacted to programs of voluntary disclosure of environmental information. The study combines a qualitative content analysis of 15 companies' reports, belonging to the material sector, to identify the IM strategies adopted, and a quantitative approach to test the main differences of water references between years, industries and regions. The results show that, among three identified IM strategies (justification and commitment, self-promotion and authorisation), self-promotion strategies increased in 2016 as companies reacted to the program for voluntary disclosure of environmental information through strategies of legitimation and image protection.

Drivers of integrated reporting by state-owned enterprises (SOEs) in Europe are examined in the study by Francesca Manes-Rossi, Giuseppe Nicolò, Adriana Tiron Tudor and Gianluca Zanellato (Manes-Rossi et al., 2021), who present a longitudinal analysis of the level of integrated reporting disclosure in a sample of European SOEs, from 2013 to 2017, in accordance with the IIRC's framework requirements (IIRC, 2013). During this four-year period, an increasing level of disclosure is observed, and the statistical analysis confirms the positive association between the level of disclosure and government ownership, external assurance, investor protection and GRI guideline adoption. In particular, in line with previous studies (Frias-Aceituno et al., 2014; Kiliç and Kuzey, 2018), the results show a positive relationship between GRI adoption and integrated report disclosure, confirming the importance of the GRI guidelines for the organisations that adopt them. Familiarity with these guidelines makes it easier to adopt integrated reporting and provide a higher degree of disclosure, while the multi-stakeholder approach typical of GRI allows SOEs to encompass a wider forum of stakeholders, thereby enhancing the legitimacy discourse with the social environment in which they operate (La Torre et al., 2018; Venturelli et al., 2017). From an evolutionary perspective, the adoption of the GRI guidelines serves as a fundamental roadmap for drafting integrated reporting, supporting SOEs in providing information on the societal value created.

The paper by Laura Rocca, Davide Giacomini and Paola Zola (Rocca et al., 2021) examines and assesses local governments' use of social media in disclosing environmental actions, plans and information as a new opportunity to improve accountability to citizens. This approach should allow local governments to obtain organisational legitimacy and the related sentiment of citizens' judgement. Based on analysis of 39 local governments' public pages on Facebook, the researchers computed the sentiment of citizens' comments, providing a "sentiment analysis" based on different approaches - one using a lexicon dictionary and the other using convolutional neural networks. The results of the study indicate that, even if local governments use Facebook to disclose environmental issues, focusing on their main interest in obtaining organisational legitimacy, there is a clear divergence of interest in environmental topics between local governments and citizens, in a dialogic accountability framework.

The study by Chairani and Sylvia Veronica Siregar (Chairani and Siregar, 2021) is based on a sample of listed companies in the ASEAN 5 (Indonesia, Malaysia, the Philippines, 
Singapore and Thailand) during the years 2014 to 2018, with total observations of 680 firmyears. The focus of the study is to examine the effect of enterprise risk management (ERM) on financial performance and firm value, as well as the moderating role of environmental, social and governance (ESG) performance. The paper shows that ERM has an insignificant effect on financial performance and firm value. However, the effect of ERM on firm performance and value is significant in the presence of ESG. Moreover, ESG has a significant moderating role.

\section{Discussion}

\subsection{Insights from prior research on corporate (sustainability) reporting}

The evolution that emerges from empirical evidence collected by prior research and practice on sustainability reporting allows discussion of the most recent organisational and professional challenges in the corporate reporting field. As far as we have observed, the need for new 'spaces' for corporate reporting is out of the question. Also companies less pressed by the sustainability urgencies of their stakeholders are seeking ways to drive a new era. Regardless of whether this will bring each organisation to a refurbished edition of the 'old' environmental and social reporting, to a new sustainability approach, or to an integrated approach, the need is undisputable and moves organisations towards significant changes. The challenge for every organisation is to enter these new spaces as rapidly as possible to be ready to satisfy this need, which is growing fast.

The way these changes could happen is mostly related to how new spaces are populated by new actors. There we find many differences, depending on organisations' force and willingness to engage with new expertise inside reporting departments, or to leverage on external skills, to be found outside the reporting department of the organisation or from consultants. This question does not have a single answer, but is connected to many organisations' features, including their dimension and possibility to enlarge with new competencies, their openness to new knowledge, the pressure exerted by stakeholders about devoting attention to new themes, and the availability of expertise to be used in the accounting and reporting departments of each organisation. Thus, the new challenge is to provide organisations with new expertise, however they obtain it, either within or outside the accounting and reporting department.

Doubt regarding the availability of sustainability expertise used in accounting and reporting departments is relevant, as its solution depends on the capability of the accounting profession and its professionals to advance in their jurisdiction towards the new sustainability themes and their willingness to consider it inside the boundaries of their work. It means an area of practice needs to be embedded in the more traditional profession, to avoid interferences by professionals usually not dealing with reporting. One cannot take for granted the desire of accounting professionals to enlarge their old limits in these new directions. Until a few years ago, there was an overall denial of this possible extension, as many accountants still thought it was beyond the boundaries of their culture. However, the situation is rapidly changing, pushed by the accounting and auditing firms that recognise a new area of business within sustainability, and an unexpected enlargement of their fields of action. Thus, the real challenge for accountants is to consider a rapid embedding of the new sustainability themes in their ancient profession, and to arrange and favour the (re) production of such intellectual capital among new professionals.

This path could be strongly forged by policy makers, accounting standard setters, public regulators and enforcement authorities on accounting and governance, which have all been undergoing a recent shift towards these themes, even when they had no previous experience in them, as recently occurred for the IFRS Foundation. All these institutions, which are 
MEDAR 29,3 seeking new expertise even for themselves, are placing pressure on those who could provide this new expertise. Thus, standard setters and public institutions could promote a boost to an augmented interest for these themes, as well as a new job market, in which accountants can have a say. The process depicted above is currently resulting in a transformation of the social order within the organisational field of reporting. There is an emerging need to encourage access to new professional capitals that must be generated and reproduced inside the "new" organisational fields. This is occurring inside organisations (mainly reporting departments), as well as being mirrored outside them at different levels - in professions, accounting firms, standard setters, legislators and regulators.

At first, the Certified Public Accountant (CPAs) are fully engaged in this enhancement, where new themes must be studied and integrated in the traditional domains of accountants. Owing to the convergence towards the new themes of many kind of professions, accountants should be fast in learning them, to diffuse and reproduce new professional capitals, avoiding new incoming professionals - especially those coming from nonaccounting disciplines, but confident with the expertise required by the "sustainability world" (e.g. environmental engineers) - subtract working spaces to their job. They risk losing primacy in the entire reporting process, where other consultants might be able to enter with expertise unknown to accountants and move all the processes into their main domains by offering new overall services. In contrast, if it became accepted that the new areas of practice could be occupied by the "renewed" CPA, their strength would be represented by their shared (accounting) language, rhetoric about reporting disclosure and categorisations developed from decades of practice, which could be used not only as an entry barrier to defend their position but also as unifying tools to allow the new themes to enter the old domain and enable fruitful reproduction of professional capital. Given the large spectrum of traditional CPA fields, as well as an acquired habitude to talk and deal with the accounting and reporting departments of their customers, CPAs have a great opportunity to occupy a relevant space into the fields.

Seemingly, accounting firms oversee the professional reporting market and do not overlook the richness of the new fields, where a complete spread of the required knowledge can be achieved. This offers an advantage to accounting firms in new domains, and a rich opportunity to offer complete services to their customers. The attempt to convert to the new fields some of the personnel usually engaged in traditional corporate advising, or in auditing procedures, is not just expedient (useful to enlarge or preserve accounting firm turnover) to avoid investing money in recruiting new personnel, but could leverage on an acquired common rhetoric inside these firms and a shared habit to categorise in the traditional accounting fields, which would be useful to face the challenges of the new fields. This has always been a typical feature of accounting firms that could bring them rapidly into the new domains.

Standard setters are also involved in this challenging shake-up of the fields involved in reporting - both those already devoted to sustainability (e.g. the SASB) or close to these topics (e.g. the IIRC) and those who have been far from it in the past, such as the International Accounting Standards Board or domestic standard setters in many countries. Many of them are wondering about the need to occupy the new fields, but the problem is their lack of tradition in sustainability matters and competition in occupying the new fields. In the debate regarding the standardisation of non-financial and sustainability reporting, an unwritten and concealed fight between a regional (and sometimes domestic) and global approach is emerging. If standard setters were able to use their ability to categorise and their rhetoric ability to issue reporting standards, they could have a chance to enlarge their field and promote a new reproduction of intangible knowledge about these matters. 
While legislators themselves perceive the need to fill the space with new rules to regulate the diffusion of sustainability reporting practices suggested or mandated by regulators and standard setters, here the discussion is about the choice between a regional versus global model with which rules must comply. The global relevance of the choice involved in sustainability processes is testified, for instance, by the commitment demonstrated to the United Nations SDGs, to which many companies are referring in their management and governance decisions and, consequently, in sustainability reporting. Moreover, in this field, legislators are very unwilling to relinquish their authority, and thus occupy the new space. reporting This explains, for instance, the anticipatory move of the European Union, which:

- found a way to address sustainability through a directive, issued in 2016, directed towards the states in the union; and

- is currently planning to rethink the same directive to update the requirements to be one of the more advanced territories in promoting sustainability reporting.

Seemingly, enforcement and regulatory authorities are seeking new spaces in which to exert their activity and controls, even if they still do not have the relevant expertise to enter and play a role in these new domains.

\subsection{Additional insights from the special issue papers}

In respect to the organisational and professional challenges associated with the more recent evolution of corporate reporting - which testifies an increasing and more integrated space for sustainability - the articles accepted in the special issue demonstrate a commitment towards sustainability as a general and irreversible direction to be followed by many kinds of organisations in diverse settings (such as private companies in numerous sectors, listed companies, SOEs, NGOs and local governments in developing countries and Arab Middle East countries). Sustainability gets its role in current emerging culture of these times (Bebbington et al., 2014). This path is much more effective when it is pushed by a real willingness of the involved organisations to engage with sustainability, rather than by a mandatory constraint ruled by the law, as this willingness generates the possibility to drive organisations towards sustainability reporting and to redesign related organisational fields.

Further, given the time that their research was developed, the special papers developed rely on organisational settings, where the main concern seems to be "enhancing sustainability" in corporate reporting and communications, rather than "integrating sustainability" in a more holistic manner (refer to our corporate reporting evolution for these phases), with the exception of a few works in the special issue. At the same time, the special issue papers do not engage with historical analysis of the sustainability reporting evolution in the phases where sustainability was neglected or developed only at niche level.

As mainly developed in the "enhancing sustainability" phase, the papers show how the path engaged requires new organisational spaces, where people can offer their support to solve technical questions and move towards sustainability reporting. Many papers demonstrate how these spaces have been found and have been rapidly populated by new expertise. We recognise that these spaces were called and claimed for different and sometimes opposing reasons: a real attention to new coming themes; a curiosity towards new emerging subjects; a desire to improve the conditions of the earth and human beings; a way to help improve business (Adams, 2017) with new generations (such as millennials); a way to satisfy needs encouraged by an active role of schools (Adams et al., 2011); and a means to legitimise behaviours (Lai et al., 2016; O’Dwyer, 2002) and business choices not yet aligned with the new times, owing to a late perception of their relevance or to the conviction sustainability is just a fad. 
MEDAR 29,3

Moreover, the papers show how the new required expertise is strictly intertwined with a traditional culture in accounting and reporting, especially when already known (and traditional) problems arise, such as (see those considered in the articles of the special issue) IM, the use of KPIs as a reporting instrument, the link with ERM and related procedures, the relation between reporting and social media, the link between traditional accounting and integrated reporting, ways to disclose sustainability issues, and how sustainability performance can be disclosed alongside traditional corporate performance. This is relevant to consider the link between the boundaries and the jurisdiction of accounting professions when sustainability reporting is involved, as well as the role of traditional accountants and managers in shepherding the new professional requirements.

As discussed in some articles of the special issue, the relationship between sustainability and integrated reporting is increasing in both practice and research settings (de Villiers and Maroun, 2017). Whether it has been adopted as a new way to tell a story about the organisation or as a narrative source of a socialising form of accountability (Lai et al., 2018), we can imagine its active role in proposing an innovative form of reporting that offers the opportunity to greater legitimation of a broad vision of each organisation. However, in the special issue papers, the way professional jurisdiction and boundaries can be changed and the capability of (re-)producing knowledge coherently with the sustainability shift is present in the background. The lack of investigation about these "professional" aspects is, to some extent, a limitation of our analysis, yet offers the opportunity to suggest new paths of research that can be very fruitful. Based on this research gap, the next section develops an agenda for future research.

\section{Conclusion and research agenda}

The research frame developed in accordance with Suddaby and Viale's (2011) theorisation of how professionals reshape organisational fields has provided an all-embracing logic for interpreting the interrelated organisational and professional challenges associated with corporate (sustainability) reporting. The papers included in the special issue on "new challenges in sustainability reporting" have further helped detail relevant recent organisational challenges, while the professional aspects largely remain unveiled. This confirms that sustainability reporting research is usually developed by focusing on either organisational or professional aspects, thus neglecting interrelations among related challenges. Further, given the time at which their research was developed, the special papers developed rely on organisational settings that appear to align with the phase of "enhancing sustainability" in corporate reporting and communications, with a lack of focus on the emerging or incoming challenges associated with the phase of "integrating sustainability". As a result, several research opportunities exist in the following avenues:

(1) Further research can explore the new spaces that sustainability matters are expected to occupy in the future, in response to the lively debate - at both political and professional levels - about the future of corporate reporting. We expect research may contribute to answer the following research questions:

- To what extent is an integration of sustainability and financial matters possible and useful for a wide range of stakeholders?

- Is there any possibility that some matters may enter or exit the current "umbrella" of sustainability/ESG matters (e.g. a more substantial inclusion of intangibles)? 
- What is the role for integrated reports in the near future? Will it be institutionalised by an increasing number of companies or "substituted" by new reporting outlets?

(2) Research can focus on the new actors involved in corporate (sustainability) reporting. In this respect, we can imagine a redefinition of the role of accountants within the corporate reporting landscape, and scholars may address the following research questions:

- What is the future of "traditional" accounting departments?

- What is the space for accountants in the political debates on sustainability (reporting)?

- To what extent financial standard setters can enter the field of sustainability reporting?

- What is the role of financial and non-financial stakeholders in driving the future evolution of sustainability reports?

- Is there any possibility for greater gender balance in professional settings, especially where sustainability is concerned?

(3) Future studies can investigate the new boundaries and new rule systems underlying the changes in the expertise involved in corporate (sustainability) reporting. The recent convergence of policy makers, regulators, enforcement authorities and standard setters on sustainability matters is expected to increase the relevance of changes in professions, including their knowledge, boundaries and jurisdiction. The way different professionals variously engaged with corporate reporting can obtain a broad sustainability expertise is a concern to be faced soon by professional bodies. Future empirical analyses are urged to address the following questions:

- Is there a standard setter that can get the better of others? Does it already exist or is it yet to be born? What will be the role of standard setters in niche/ fragmented aspects of sustainability?

- What will be the role of regulators in driving changes in the field of sustainability reporting?

- What are the boundaries that practitioners will have to overcome to favour a genuine corporate engagement with sustainability (reporting)?

(4) Future research can investigate the reproduction of social capital - that is, how sustainability expertise is generated or reproduced. Although we have already seen a growing increase in sustainability culture in several settings, we believe there is room and need for further progress. As such, we invite investigation of the following research questions:

- What are the main obstacles to the reproduction and diffusion of sustainability expertise within organisations?

- How can accountant departments acquire the sustainability expertise increasingly required in the corporate reporting field?

- What are the more appropriate mechanisms to allow traditional accountants to cooperate with sustainability experts?

(5) Future research may also develop these research avenues by means of a historical perspective (Carnegie and Napier, 1996) on the evolution of sustainability reporting in diverse settings, particularly in contexts where the evolution differs from that depicted in this paper. These settings may refer to particular industries that 
MEDAR 29,3 experienced sustainability problems much earlier than those to which this paper implicitly refers. This research avenue can illuminate the path of those companies that are "discovering" sustainability in the present context, where sustainability is multifaceted and increasingly integrated with financial matters. Further, this research avenue could provide meaningful answers to the following questions:

- What was the role of professions in shaping the organisational field of reporting at different times?

- Why have some organisations started to engage with sustainability at different times?

- Is this diachronic engagement with sustainability somehow related to a differentiated development of accounting or non-accounting professions?

- How did sustainability expertise emerge and hybridise financial reporting preparers during the first experiments of social and environmental reports during the 1980 s to 1990 s?

In line with our research frame, we invite future research to develop these research avenues by unveiling the often-invisible interconnections between organisational and professional dynamics in the expanding and lively field of sustainability reporting. However, we hope that accounting scholars will refer to a broad spectrum of theories or develop new theories to enrich our understanding of the inevitable evolutionary process to which corporate (sustainability) reporting is exposed. To conclude, while a number of accounting scholars have already demonstrated a competent and passionate involvement in researching sustainability reporting, the above-mentioned research avenues demonstrate that the research opportunities are far from being exhausted. We sincerely hope to make our own small contribution.

\section{References}

Abbott, A. (1988), The System of Professions: An Essay on the Division of Expert Labour, Chicago University Press, Chicago.

Adams, C.A. (2017), "Conceptualising the contemporary corporate value creation process", Accounting, Auditing and Accountability Journal, Vol. 30 No. 4, pp. 906-931.

Adams, C.A., Heijltjes, M.G., Jack, G., Marjoribanks, T. and Powell, M. (2011), "The development of leaders able to respond to climate change and sustainability challenges: the role of business schools", sustainability accounting", Sustainability Accounting, Management and Policy Journal, Vol. 2 No. 1, pp. 165-171.

Argento, D., Grossi, G., Persson, K. and Vingren, T. (2019), "Sustainability disclosures of hybrid organizations: Swedish state-owned enterprises", Meditari Accountancy Research, Vol. 27 No. 4, pp. 505-533.

Bansal, P. and Hoffman, A.J. (2013), The Oxford Handbook of Business and the Natural Environment, Oxford University Press, Oxford.

Bebbington, J., Unerman, J. and O'Dwyer, B. (Eds) (2014), Sustainability Accounting and Accountability, Routledge.

Bebbington, J., Gray, R., Thomson, I. and Walters, D. (1994), “Accountants' attitudes and environmentallysensitive accounting”, Accounting and Business Research, Vol. 24 No. 94, pp. 109-120.

Beckert, J. (2010), "How do fields change? The interactions of institutions, networks, and cognition in the dynamic of markets", Organization Studies, Vol. 31 No. 5, pp. 605-627.

Burchell, S., Clubb, C., Hopwood, A., Hughes, J. and Nahapiet, J. (1980), "The roles of accounting in organizations and society”, Accounting, Organizations and Society, Vol. 5 No. 1, pp. 5-27. 
Burritt, R.L. and Schaltegger, S. (2010), "Sustainability accounting and reporting: fad or trend?", Accounting, Auditing and Accountability Journal, Vol. 23 No. 7, pp. 829-846.

Burritt, R.L. and Tingey-Holyoak, J. (2011), "Sustainability accounting research and professional practice: mind the gap", in Evans, E., Burrit, R. and Guthrie, J. (Eds), Bridging the Gap between Academic Accounting Research and Professional Practice, University of South Australia and CPA Australia, Sydney, pp. 110-119.

Carnegie, G.D. and Napier, C.J. (1996), "Critical and interpretive histories: insights into accounting's present and future through its past", Accounting, Auditing and Accountability Journal, Vol. 9 No. 3, pp. 7-39.

Carungu, J., Di Pietra, R. and Molinari, M. (2021), "Mandatory vs voluntary exercise of non-financial reporting: does a normative/coercive isomorphism facilitate an increase of quality?", Meditari Accountancy Research, Vol. 29 No. 3, pp. 449-476.

Chairani Siregar, S.V. (2021), "The effect of enterprise risk management on financial performance and firm value: the role of the quality of environmental, social and governance disclosure (ESG)", Meditari Accountancy Research, Vol. 29 No. 3, pp. 647-670.

Chenhall, R.H. (2007), "Theorising contingencies in management control systems research", in Chapman, C.S., Hopwood, A.G. and Shields, M.D. (Eds), Handbook of Management Accounting Research, Vol. 1, 1st ed., Amsterdam, The Netherlands; Oxford: Elsevier, pp. 163-205.

Cho, C.H. (2020), "CSR accounting 'new wave' researchers: 'step up to the plate' ... or 'stay out of the game”, Accounting and Management Information Systems, Vol. 19 No. 4, pp. 626-650.

Clune, C. and O'Dwyer, B. (2020), "Organizing dissonance through institutional work: the embedding of social and environmental accountability in an investment field", Accounting, Organizations and Society, Vol. 85, pp. 1-25.

Contrafatto, M. (2014), "The institutionalization of social and environmental reporting: an italian narrative", Accounting, Organizations and Society, Vol. 39 No. 6, pp. 414-432.

Dacin, M.T., Goodstein, J. and Scott, W.R. (2002), "Institutional theory and institutional change: introduction to the special research forum", Academy of Management Journal, Vol. 45 No. 1, pp. 45-57.

De Micco, P., Rinaldi, L., Vitale, G., Cupertino, S. and Maraghini, M.P. (2021), "The challenges of sustainability reporting and their management: the case of estra", Meditari Accountancy Research, Vol. 29 No. 3, pp. 430-448.

de Villiers, C. and Maroun, W. (Eds) (2017), Sustainability Accounting and Integrated Reporting, Routledge, New York, NY.

de Villiers, C. and Sharma, U. (2020), "A critical reflection on the future of financial, intellectual capital, sustainability and integrated reporting", Critical Perspectives on Accounting, Vol. 70, pp. 1-13.

de Villiers, C., Hsiao, P.C.K. and Maroun, W. (Eds) (2020), The Routledge Handbook of Integrated Reporting, Routledge, New York, NY.

de Villiers, C., Rinaldi, L. and Unerman, J. (2014), "Integrated reporting: insights, gaps and an agenda for future research", Accounting, Auditing and Accountability Journal, Vol. 27 No. 7, pp. 1042-1067.

Deegan, C. and Unerman, J. (2011), Financial Accounting Theory: European Edition, McGraw Hill, London.

Del Baldo, M. (2017), "The implementation of integrating reporting $<\mathrm{IR}>$ in SMEs", Meditari Accountancy Research, Vol. 25 No. 4, pp. 505-532.

Dissanayake, D. (2021), "Sustainability key performance indicators and the global reporting initiative: usage and challenges in a developing country context", Meditari Accountancy Research, Vol. 29 No. 3, pp. 543-567.

Du Toit, E. (2017), “The readability of integrated reports", Meditari Accountancy Research, Vol. 25 No. 4, pp. 654-674.

Du Toit, E., van Zyl, R. and Shütte, G. (2017), "Integrated reporting by South African companies: a case study", Meditari Accountancy Research, Vol. 25 No. 4, pp. 654-674.

\section{Sustainability} reporting

425 
MEDAR 29,3

Dumay, J. and Dai, T. (2017), "Integrated thinking as a cultural control", Meditari Accountancy Research, Vol. 25 No. 4, pp. 574-604.

Dumay, J., Bernardi, C., Guthrie, J. and La Torre, M. (2017), "Barriers to implementing the international integrated reporting framework: a contemporary academic perspective", Meditari Accountancy Research, Vol. 25 No. 4, pp. 461-480.

Emenyonu, E. and Gray, S.J. (1992), "EC accounting harmonisation: an empirical study of measurement practices in France, Germany and the UK", Accounting and Business Research, Vol. 23 No. 89, pp. 49-58.

European Financial Reporting Advisory Group (EFRAG) (2020), "Successful launch of the project on preparatory work for the elaboration of possible EU non-financial reporting standards", available at: https://www.efrag.org/News/Project-442/Successful-launch-of-the-project-onpreparatory-work-for-the-elaboration-of-possible-EU-non-financial-reporting-standards? AspxAutoDetectCookieSupport=1 (accessed 30 January 2021).

Farneti, F., Casonato, F., Montecalvo, M. and de Villiers, C. (2019), "The influence of integrated reporting and stakeholder information needs on the disclosure of social information in a stateowned enterprise", Meditari Accountancy Research, Vol. 27 No. 4, pp. 556-579.

Farooq, M.B. and de Villiers, C. (2019), "Understanding how managers institutionalise sustainability reporting: evidence from Australia and New Zealand”, Meditari Accountancy Research, Vol. 32 No. 5, pp. 1240-1269.

Fialho, A., Morais, A. and Pisco Costa, R. (2021), "Impression management strategies and water disclosures - the case of CDP A-list”, Meditari Accountancy Research, Vol. 29 No. 3, pp. 568-585.

Fligstein, N. (2001), "Sociological skill and the theory of fields", Sociological Theory, Vol. 19 No. 2, pp. 105-125.

Flood, J. (2011), "The re-landscaping of the legal profession: large law firms and professional reregulation", Current Sociology, Vol. 59 No. 4, pp. 507-529.

Florio, C. and Sproviero, A.F. (2021), "Repairing legitimacy through discourses: insights from the vokswagen's 2015 diesel scandal", Meditari Accountancy Research, Vol. 29 No. 3, pp. 524-542.

Flower, J. (2015), "The international integrated reporting council: a story of failure", Critical Perspectives on Accounting, Vol. 27, pp. 1-17.

Frias-Aceituno, J.V., Rodríguez-Ariza, L. and Garcia-Sanchez, I.M. (2014), "Explanatory factors of integrated sustainability and financial reporting", Business Strategy and the Environment, Vol. 23 No. 1, pp. 56-72.

Gray, R.H. and Collison, D. (2002), "Can't see the wood for the trees, can't see the trees for the numbers? Accounting education, sustainability and the public interest", Critical Perspectives on Accounting, Vol. 13 Nos 5/6, pp. 797-836.

Gray, R., Bebbington, J. and Walters, D. (1993), Accounting for the Environment, Paul Chapman Publishing, London.

Greenwood, R., Hinings, B. and Jennings, D. (2015), "Sustainability and organizational change: an institutional perspective”, in Henderson, R., Gulati, R. and Tushman, M. (Eds), Leading Sustainable Change: An Organizational Perspective, OUP Oxford, Oxford, pp. 323-355.

Greenwood, R., Suddaby, R. and Hinings, C.R. (2002), "Theorizing change: the role of professional associations in the transformation of institutionalized fields", Academy of Management Journal, Vol. 45 No. 1, pp. 58-80.

Guthrie, J., Manes-Rossi, F. and Levy-Orelli, R. (2017), "Integrated reporting and integrated thinking in Italian public sector organisations", Meditari Accountancy Research, Vol. 25 No. 4, pp. 553-573.

Horner, C. and Davidson, N. (2021), "Accounting for biodiverse wildlife corridor plantations”, Meditari Accountancy Research, Vol. 29 No. 3, pp. 502-523. 
Humphrey, C., O'Dwyer, B. and Unerman, J. (2017), "Re-theorizing the configuration of organizational fields: the IIRC and the pursuit of 'enlightened' corporate reporting", Accounting and Business Research, Vol. 47 No. 1, pp. 30-63.

IFRS Foundation (2020), “Consultation paper on sustainability reporting”, available at: https://cdn.ifrs. org/-/media/project/sustainability-reporting/consultation-paper-on-sustainability-reporting. pdf (accessed 30 January 2021).

IIRC and SASB (2020), "IIRC and SASB announce intent to merge in major step towards simplifying the corporate reporting system", available at: https://integratedreporting.org/news/iirc-and-sasbreporting announce-intent-to-merge-in-major-step-towards-simplifying-the-corporate-reporting-system/ (accessed 30 January 2021).

International Integrated Reporting Council (IIRC) (2011), "Towards integrated reporting. Communicating value in the 21th century", discussion paper, available at: https:// integratedreporting.org/wp-content/uploads/2011/09/IR-Discussion-Paper-2011_spreads.pdf (accessed 22 January 2021).

International Integrated Reporting Council (IIRC) (2013), "International integrated reporting framework", available at: http://integratedreporting.org/wp-content/uploads/2015/03/13-12-08THE-INTERNATIONAL-IR-FRAMEWORK-2-1.pdf (accessed 30 January 2021).

Ismaeel, M. and Zakaria, Z. (2019), "Perception of preparers of sustainability reports in the Middle East: contrasting between local and global", Meditari Accountancy Research, Vol. 28 No. 1, pp. 89-116.

Jones, M.J. (1996), “Accounting for biodiversity: a pilot study”, The British Accounting Review, Vol. 28 No. 4, pp. 281-303.

Jones, M.J. (2003), "Accounting for biodiversity: operationalising environmental accounting", Accounting, Auditing and Accountability Journal, Vol. 16 No. 5, pp. 762-789.

Kassim, C.K.H.C.K., Ahamad, S., Nasir, N.E.M., Nori, W.M.N.W.M. and Arifin, N.N.M. (2019), "Environmental reporting by the Malaysian local governments", Meditari Accountancy Research, Vol. 27 No. 4, pp. 633-651.

Kiliç, M. and Kuzey, C. (2018), "Assessing current company reports according to the IIRC integrated reporting framework”, Meditari Accountancy Research, Vol. 26 No. 2, pp. 305-333.

Kwakye, T.O., Welbeck, E.E., Owusu, G.M.Y. and Anokye, F.K. (2018), "Determinants of intention to engage in sustainability accounting and reporting (SAR): the perspective of professional accountants", International Journal of Corporate Social Responsibility, Vol. 3 No. 1, pp. 1-13.

La Torre, M., Sabelfelt, S., Blomkvist, M., Tarquinio, L. and Dumay, J. (2018), "Harmonizing nonfinancial reporting regulation in Europe", Meditari Accountancy Research, Vol. 26 No. 4, pp. 598-621.

Lai, A., Leoni, G. and Stacchezzini, R. (2019a), "Accounting and governance in diverse settings - an introduction”, Accounting History, Vol. 24 No. 3, pp. 325-337.

Lai, A., Melloni, G. and Stacchezzini, R. (2016), "Corporate sustainable development: is "integrated reporting' a legitimation strategy?", Business Strategy and the Environment, Vol. 25 No. 3, pp. 165-177.

Lai, A., Melloni, G. and Stacchezzini, R. (2017), "What does materiality mean to integrated reporting preparers? An empirical exploration”, Meditari Accountancy Research, Vol. 25 No. 4, pp. 533-552.

Lai, A., Melloni, G. and Stacchezzini, R. (2018), "Integrated reporting and narrative accountability: the role of preparers", Accounting, Auditing and Accountability Journal, Vol. 31 No. 5, pp. 1381-1405.

Lai, A., Panfilo, S. and Stacchezzini, R. (2019b), "The governmentality of corporate (un)sustainability: the case of the ILVA steel plant in Taranto (Italy)", Journal of Management and Governance, Vol. 23 No. 1, pp. 67-209.

Lamberton, G. (2005), "Sustainability accounting - a brief history and conceptual framework", Accounting Forum, Vol. 29 No. 1, pp. 7-26. 
MEDAR 29,3

Lawrence, T.B. and Suddaby, R. (2006), "Institutions and institutional work", in Clegg, S.R., Hardy, C., Lawrence, T.B. and Nord, W.R. (Eds), Sage Handbook of Organization Studies, Sage, London, pp. 215-254.

Lewis, L. (2000), "Environmental audits in local government: a useful means to progress in sustainable development", Accounting Forum, Vol. 24 No. 3, pp. 296-318.

Lusher, A.L. (2012), "What is the accounting profession's role in accountability of economic, social, and environmental issues?", International Journal of Business and Social Science, Vol. 3, p. 15.

McNally, M.-A., Cerbone, D. and Maroun, W. (2017), "Exploring the challenges of preparing an integrated report", Meditari Accountancy Research, Vol. 25 No. 4, pp. 654-674.

MacKenzie, D. (2009), "Making things the same: gases, emission rights and the politics of carbon markets", Accounting, Organizations and Society, Vol. 34 Nos 3/4, pp. 440-455.

Manes-Rossi, F., Nicolò, G., Tiron-Tudor, A. and Zanellato, G. (2021), "Drivers of integrated reporting by state-owned enterprises in Europe: a longitudinal analysis", Meditari Accountancy Research, Vol. 29 No. 3, pp. 586-616.

Mathews, M.R. (1997), "Twenty-five years of social and environmental accounting research: is there a silver jubilee to celebrate?", Accounting, Auditing and Accountability Journal, Vol. 10 No. 4, pp. 481-531.

Melloni, G., Stacchezzini, R. and Lai, A. (2016), "The tone of business model disclosure: an impression management analysis of the integrated reports", Journal of Management and Governance, Vol. 20 No. 2, pp. 295-320.

O’Dwyer, B. (2002), "Managerial perceptions of corporate social disclosure: an Irish story", Accounting, Auditing and Accountability Journal, Vol. 15 No. 3, pp. 406-436.

O'Dwyer, B. and Unerman, J. (2016), "Fostering rigour in accounting for social sustainability", Accounting, Organizations and Society, Vol. 49, pp. 32-40.

O'Dwyer, B. and Unerman, J. (2020), "Shifting the focus of sustainability accounting from impacts to risks and dependences: researching the transformative potential of TCFD reporting", Accounting, Auditing and Accountability Journal, Vol. 33 No. 5, pp. 1113-1141.

Özsözgün Çalişkan, A. (2014), "How accounting and accountants may contribute in sustainability?", Social Responsibility Journal, Vol. 10 No. 2, pp. 246-267.

Peña, J.A. and Jorge, M.L. (2019), "Examining the amount of mandatory non-financial information disclosed by Spanish state-owned enterprises and its potential influential variables", Meditari Accountancy Research, Vol. 25 No. 4, pp. 605-628.

Rinaldi, L., Unerman, J. and de Villiers, C. (2018), "Evaluating the integrated reporting journey: insights, gaps and agendas for future research", Accounting, Auditing and Accountability Journal, Vol. 31 No. 5, pp. 1294-1318.

Rocca, L., Giacomini, D. and Zola, P. (2021), "Environmental disclosure and sentiment analysis: state of the art and opportunities for public-sector organisations", Meditari Accountancy Research, Vol. 29 No. 3, pp. 617-646.

Rowbottom, N. and Locke, J. (2016), “The emergence of IR”, Accounting and Business Research, Vol. 46 No. 1, pp. 83-115.

Siboni, B., Sangiorgi, D., Farneti, F. and de Villiers, C. (2016), "Gender (in) accounting: insights, gaps and an agenda for future research", Meditari Accountancy Research, Vol. 24 No. 2, pp. 158-168.

Stacchezzini, R. and Lai, A. (2020), "Integrated reporting preparers: mode of cognition, stakeholder salience and integrated thinking in action", in de Villiers, C., Hsiao, P.-C.K. and Maroun, W. (Eds), The Routledge Handbook of Integrated Reporting, Routledge, London and New York, NY, pp. 269-279.

Stacchezzini, R., Melloni, G. and Lai, A. (2016), "Sustainability management and reporting: the role of integrated reporting for communicating corporate sustainability management", Journal of Cleaner Production, Vol. 136, pp. 102-110. 
Suárez-Rico, T.M., García-Benau, M.A. and Gómez-Villegas, M. (2019), "CRS communication through Facebook in the Latin American integrated market (Mila)", Meditari Accountancy Research, Vol. 27 No. 5, pp. 741-760.

Suddaby, R. and Greenwood, R. (2005), "Professionals and field-level change: institutional work and the professional project”, Current Sociology, Vol. 59 No. 4, pp. 423-442.

Suddaby, R. and Viale, T. (2011), "Professional and field-level change: institutional work and the professional project", Current Sociology, Vol. 59 No. 4, pp. 423-432.

Sukhari, A. and de Villiers, C. (2019), "The influence of integrated reporting on business model and strategy disclosures", Australian Accounting Review, Vol. 29 No. 4, pp. 708-725.

Thomson, I. (2015), "'But does sustainability need capitalism or an integrated report' - a commentary on 'the international integrated reporting council: a story of failure' by Flower, J", Critical Perspectives on Accounting, Vol. 27, pp. 18-22.

Unerman, J., Bebbington, J. and O’Dwyer, B. (2018), “Corporate reporting and accounting for externalities", Accounting and Business Research, Vol. 48 No. 5, pp. 497-522.

United Nations (World Commission on Environment and Development) (1987), Our Common Future, Oxford University Press, London.

Venter, E.R. and de Villiers, C. (2013), "The accounting profession's influence on academe: South African evidence", Accounting, Auditing and Accountability Journal, Vol. 26 No. 8, pp. 1246-1278.

Venturelli, A., Caputo, F., Cosma, S., Leopizzi, R. and Pizzi, S. (2017), "Directive 2014/95/EU: are Italian companies already compliant?”, Sustainability, Vol. 9 No. 8, p. 1385.

von Alberti-Alhtaybat, L., Alhatabat, Z. and Al-Htaybat, K. (2021), "Investigating the sustainability habitus: insights from the Aramex's sustainability practices and reports", Meditari Accountancy Research, Vol. 29 No. 3, pp. 477-501.

Walker, S.P. (2016), "Revisiting the role of accounting in society", Accounting, Organizations and Society, Vol. 49, pp. 41-50.

Welbeck, E.E. (2017), "The influence of institutional environment on corporate responsibility disclosures in Ghana”, Meditari Accountancy Research, Vol. 25 No. 2, pp. 216-240.

Whelan, T. and Douglas, E. (2021), "How to talk to your CFO about sustainability: use this tool for measuring the financial return on ESG activities", available at: https://hbr.org/2021/01/how-totalk-to-your-cfo-about-sustainability (accessed 24 January 2021).

Wilmshurst, T.D. and Frost, G.R. (2001), "The role of accounting and the accountant in the environmental management system", Business Strategy and the Environment, Vol. 10 No. 3, pp. 135-147.

Zuckermann, E. (1999), "The categorical imperative: securities analysts and the illegitimacy discount", American Journal of Sociology, Vol. 104 No. 5, pp. 1398-1438.

\section{Corresponding author}

Alessandro Lai can be contacted at: alessandro.lai@univr.it

For instructions on how to order reprints of this article, please visit our website:

www.emeraldgrouppublishing.com/licensing/reprints.htm

Or contact us for further details: permissions@emeraldinsight.com 